\title{
Liganded and Unliganded Steroid Receptor Modulation of Beta 1 Adrenergic Receptor Gene Transcription
}

\author{
THERESA C. MCNAB, YI-TANG TSENG, JOAN P. STABILA, BETHANY G. MCGONNIGAL, AND \\ JAMES F. PADBURY \\ Department of Pediatrics, Women \& Infants Hospital of Rhode Island, Brown University School of \\ Medicine, Providence, Rhode Island 02905, U.S.A.
}

\begin{abstract}
ABSTR classical model of gene regulation by hormones involves
The
a hormone-bound receptor interacting with a DNA response
element to increase or decrease gene transcription. Steroid hor-
mone regulation more commonly involves atypical cis-elements,
co-receptors, accessory proteins, and unique modes of interaction
on different genes. The thyroid hormone and retinoic acid recep-
tors belong to the super family of steroid nuclear receptors and
may modify gene expression even in the absence of ligand
binding. In these studies, we characterized thyroid receptor- and
retinoic acid receptor-mediated regulation of $\beta 1$ adrenergic re-
ceptor ( $\beta 1$ AR) gene expression. Using cloned fragments of the
ovine $\beta 1$ AR in a luciferase reporter vector, we examined the
effects of thyroid receptor and retinoic acid receptor, alone and in
combination with T3 or retinoic acid on $\beta 1$ AR expression. We
examined expression in SK-N-SH neuroblastoma cells, CV-1
fibroblasts, and, in neonatal rat, primary cardiomyocytes. We
demonstrated that even in the absence of ligand binding, thyroid
\end{abstract}
The classical model of gene regulation by hormones involves a hormone-bound receptor interacting with a DNA response element to increase or decrease gene transcription (1, 2). It is now appreciated that this model of hormonal regulation of gene expression is simplistic and may be the exception rather than the rule. For instance, classical models cannot explain the hormonal regulation of genes that lack canonical consensus DNA elements. These models also do not account for changes in hormonal regulation of gene expression at different developmental stages, differential regulation in different tissues, and other complexities of hormonal regulation. Steroid hormone regulation more commonly involves atypical cis-elements, co-receptors, accessory proteins, and unique modes of interaction on different genes (3).

Received February 2, 2001; accepted June 5, 2001.

Correspondence and reprint requests: James F. Padbury, M.D., Department of Pediatrics, Women \& Infants Hospital of Rhode Island, 101 Dudley Street, Providence, RI 02905, U.S.A.; e-mail: James_Padbury@brown.edu

Supported, in part, by a grant from the United States Public Health Service (5 P01 HD11343). receptor and retinoic acid receptor can significantly increase $\beta 1 \mathrm{AR}$ transcription activity. This effect is important in the developmental transition in $\beta 1 \mathrm{AR}$ expression during fetal and postnatal life. (Pediatr Res 50: 575-580, 2001)

$\quad$ Abbreviations
BAR, $\beta$ adrenergic receptor
GRE, glucocorticoid response element
TRE, thyroid response element
TR, thyroid receptor
RAR, retinoic acid receptor
AR, androgen receptor
RXR, retinoid X nuclear co-receptor
TRAM, thyroid receptor adaptor molecule
SRC, steroid receptor co-activator
RSV-CAT, Rous sarcoma virus promoter-chloramphenicol
acetyl transferase expression vector

The TR and RAR belong to the super family of steroid nuclear receptors $(1-4)$. TR and RAR bind to DNA as heterodimers with RXR (4). There is also a family of coregulators that positively and negatively regulate transcriptional activation from a variety of cis-elements in specific genes. Recently, it has been recognized that modulation of gene expression by steroid nuclear receptors may be independent of ligand binding to the steroid receptor. TR can bind to DNA in the absence of its ligand (thyroid hormone) and can regulate transcription both positively and negatively from a variety of promoters (5-7). Transactivation by TR in the absence of hormone can require cell-specific factors but may occur even with promoters that do not contain clearly defined TRE $(8,9)$. Similar observations have been reported for RAR (10). A precise physiologic context for nonligand-dependent regulation of transcription by these receptors has not been shown.

We are interested in the hormonal regulation of the $\beta 1$ adrenergic receptor ( $\beta 1 \mathrm{AR})$ during development (11-18). The $\beta 1 \mathrm{AR}$ is a member of the seven transmembrane domain, 
G-protein coupled receptor superfamily (19). This large class of signaling molecules includes the receptors for catecholamines, neurotransmitters, hormones, chemotaxins, and special senses. The $\beta 1 \mathrm{AR}$ is most highly expressed in the heart, where it is the major $\beta$ AR subtype $(19,20)$. In contrast to the $\beta 2$ adrenergic receptor ( $\beta 2 \mathrm{AR})$ gene, which has been well characterized $(21,22)$, less is known about the $\beta 1 \mathrm{AR}$ and its transcriptional regulation. The gene encoding the $\beta 1 \mathrm{AR}$ contains a TATA-less promoter and the transcription start site does not resemble an initiator element $(16,23)$. Sequence analysis has identified several putative GRE and TRE in the human, rat, and ovine $\beta 1 \mathrm{AR}$ promoters $(16,24,25)$. An inverted cAMP response element has also recently been identified in the ovine $\beta 1$ adrenergic receptor gene promoter (26).

It is well established that $\beta 1 \mathrm{AR}$ expression in adult animals and humans is influenced by thyroid hormones (27-32). Studies from our group and others have shown that the $\beta 1 \mathrm{AR}$ is expressed during late fetal development in both rodents and sheep and coupled to important physiologic responses (11-18). Interestingly, thyroid hormone alone or in combination with corticosteroids does not further increase $\beta 1 \mathrm{AR}$ receptor expression or density during fetal or early postnatal development $(17,18,33,34)$. This is in marked contrast to the studies in older animals and humans where thyroid hormones have clearly been shown to increase $\beta 1 \mathrm{AR}$ expression and the increase has been shown to be at the level of gene transcription (28).

The purpose of the present studies was to characterize thyroid hormone and TR-mediated regulation of $\beta 1 \mathrm{AR}$ gene expression. Because of their importance in cardiac development and because they have been shown to have important co-regulatory effects on other genes, we also examined the role of retinoic acid and the retinoid receptor on $\beta 1 \mathrm{AR}$ expression (35-37). We report here evidence for transcriptional regulation of the $\beta 1 \mathrm{AR}$ gene by TR and RAR. These data suggest several mechanisms to explain the developmental transition in $\beta 1 \mathrm{AR}$ expression during fetal and postnatal life.

\section{METHODS}

Cell lines and cell culture. Unless otherwise noted, all chemicals were obtained from Sigma Chemical and all cell culture reagents were obtained from GIBCO BRL. Several cell lines were considered for expression studies. Rat C-6 glioma cells have been used extensively as a model of pharmacologic regulation of adrenergic receptors $(38,39)$. Likewise, human SK-N-SH neuroblastoma cells express adrenergic receptors and have been used for studies of pharmacologic regulation of $\beta A R$ expression (26). CV-1 cells are a green monkey kidney fibroblast cell line that do not express endogenous TR or RAR. In replacement studies, CV-1 cells have been used extensively to explore the role for nuclear hormone receptors, co-receptors, and co-activators in gene regulation $(7,10)$. To verify the veracity of expression in nontransformed cells, primary cardiomyocytes were also studied. Rat cardiomyocytes express adrenergic receptors that mediate important physiologic and adaptive effects $(40,41)$.
All cell lines were used in transient transfection assays to analyze the promoter constructs described below. We examined the effects of thyroid hormone alone and in combination with TR expression vectors. Because our results demonstrated unliganded transcriptional activation of the $\beta 1 \mathrm{AR}$ promoter and because similar results have been seen by other investigators for several of the nuclear hormone receptors, we also examined the effects of retinoic acid and a RAR expression vector on the transcriptional activation of the $\beta 1$ promoter constructs.

The SK-N-SH cells were cultured in Dulbecco's modified Eagle medium supplemented with $10 \%$ fetal bovine serum (FBS), $50 \mathrm{unit} / \mathrm{mL}$ penicillin $\mathrm{G}$, and $50 \mu \mathrm{g} / \mathrm{mL}$ streptomycin in a humidified $37^{\circ} \mathrm{C}$ incubator containing $5 \% \mathrm{CO}_{2}$. The CV-1 cells were cultured in Minimal Essential Media plus glutamine, $10 \% \mathrm{FBS}, 50 \mathrm{unit} / \mathrm{mL}$ penicillin $\mathrm{G}$, and $50 \mu \mathrm{g} / \mathrm{mL}$ streptomycin. For transfection experiments, the cells were plated in 24-well culture plates at 80,000 cells per well and allowed to grow to $60-70 \%$ confluency. In most experiments, a total of $0.4 \mu \mathrm{g}$ of DNA $(0.2 \mu \mathrm{g}$ individual $\beta 1 \mathrm{AR}$ plasmids or the empty pGL2 vector and $0.2 \mu \mathrm{g}$ of the steroid nuclear receptor vector or empty plasmid) along with $0.2 \mu \mathrm{g}$ RSV-CAT DNA were transfected. All cells except the CV-1 cells were maintained in media containing stripped sera during the transfection experiments. The CV-1 cells were well maintained without sera present during transfections.

Primary neonatal rat cardiomyocytes were harvested from 3-d-old Sprague-Dawley rat pups and prepared using commercially available reagents (Worthington Biochemicals, Freehold, NJ, U.S.A.). All studies were approved by the Institutional Animal Care and Use Committee. Rat cardiomyocytes were isolated with minor modifications of the manufacturer's recommendations (37). Following isolation, the cardiomyocytes were plated at 250,000 cells/well in F-10 medium containing $10 \%$ FBS and allowed a $24-36 \mathrm{~h}$ recovery period before any transfection experiments. Like the SK-N-SH cells, primary neonatal rat cardiomyocytes were maintained in media containing stripped sera during transfection experiments.

Plasmids, constructs, and vectors. The ovine $\beta 1 \mathrm{AR}$ gene was cloned and sequenced in our laboratory (16). Nested deletion constructs of the promoter region ranging from the full length promoter ( $-2333 \mathrm{bp}$ ) to the point where the transcription start site was deleted were subcloned into a luciferase reporter vector (pGL2basic, Promega, Madison, WI, U.S.A.) as described previously $(18,26)$. Expression vectors containing TR or RAR were co-transfected with the promoter or relevant deletion constructs. Expression vectors for the steroid nuclear receptors and co-activators were kindly supplied by Dr. William Chin (Harvard University).

Gene expression analysis. Transfections were carried out using Lipofectin (GIBCO-BRL). In preliminary experiments, the ratio of DNA to transfection reagent and the total amount of DNA used in transfection experiments with each cell line were varied over a wide range. In subsequent experiments, the optimal ratio was used. In primary cardiomyocytes, the efficiency of transfection with Lipofectin was low. Noah et al. (42) have reported that the optimal transfection efficiency of primary cardiomyocytes was seen with Fugene 6 (Roche Molec- 
ular Biochemical, Summerville, NJ, U.S.A.). In preliminary studies, we demonstrated 5- to 10-fold greater efficiency of transfection for primary cardiomyocytes with Fugene 6 that was optimized and used in all subsequent experiments with these cells. After transfection, all cells were allowed to express for $16-20 \mathrm{~h}$ and then the cells were washed and treated with either vehicle $(2.5 \mu \mathrm{M} \mathrm{NaOH})$ or $100 \mathrm{nM}$ thyroid hormone (T3) for an additional $24 \mathrm{~h}$. In experiments using retinoic acid, the cells were washed and treated with either vehicle $(0.01 \%$ DMSO) or $1 \mu \mathrm{M}$ retinoic acid (RA). Empty vector alone and vehicle controls were included in all experiments. An RSVCAT construct under the control of a strong eukaryotic promoter was included in all experiments to control for transfection efficiency. Transcription activity was determined on cell lysates by assay of luciferase and CAT as described previously (18). Activity was expressed relative to control conditions and/or empty vector after correction for transfection efficiency. Results are presented as mean \pm SEM and represent the average of two to three experiments carried out in quadruplicate.

\section{RESULTS}

Prior studies in our laboratory suggested that $\mathrm{T} 3$ alone or in combination with dexamethasone did not increase transcription activity of the $\beta 1 \mathrm{AR}$ promoter construct in C6 cells (18). The lack of thyroid responsiveness could be due to low levels of expression of endogenous TR in the cell lines used or absence of co-regulators for thyroid responsiveness. We have used SK-N-SH neuroblastoma cells, which express $\beta 1 \mathrm{AR}$, for transcription studies extensively $(18,26)$. We therefore examined the effects of co-expression of TR with the $\beta 1 \mathrm{AR}$ promoter in this cell line. Co-transfection of the TR $\beta$ with the full-length $\beta 1 \mathrm{AR}$ promoter was associated with a significant increase in gene expression (Fig. 1). The addition of T3 decreased rather than increased transcriptional activation. These findings are consistent with so-called "unliganded" receptor-mediated activation. Unliganded transcriptional activation has been reported in a number of cell lines and with several different promoter constructs. Further, the reduction in transcriptional activity after the addition of $\mathrm{T} 3$ is consistent with the presence of a

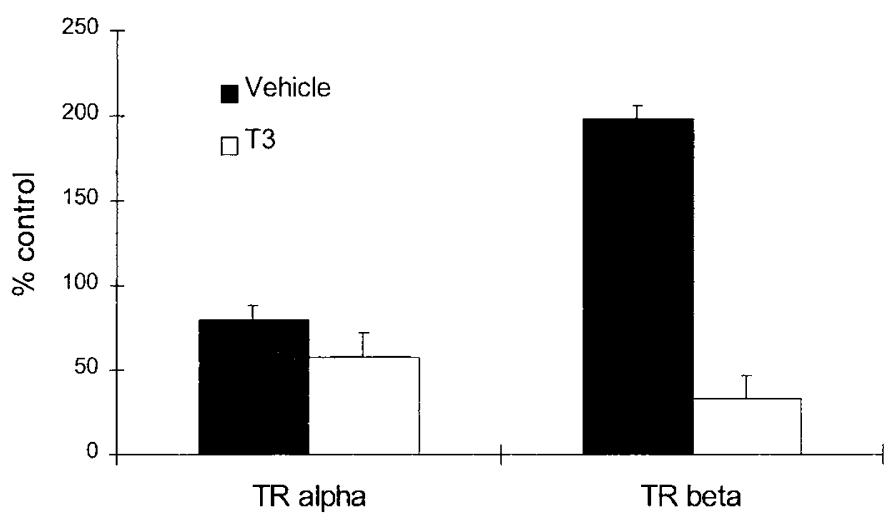

Figure 1. The effects of thyroid receptor alone or in combination with thyroid hormone. $\beta 1 \mathrm{AR}$ expression is in SK-N-SH cells and is expressed as percentage of control/empty plasmid that was treated identically. The $\beta 1 \mathrm{AR}$ expression vector was co-transfected with either TR $\alpha$ or TR $\beta$ as indicated. Mean \pm SEM. "negative" element. Figure 1 also shows in SK-N-SH cells that $\operatorname{TR} \beta$, not TR $\alpha$, increased transcriptional activity, even if unliganded. This is not surprising as TR $\beta$ has been suggested by other investigations to have a more important physiologic role. In data not shown, we examined the effects of co-expression of TR in C6 cells and observed no effect of TR alone or in combination with thyroid hormone.

Transcriptional activation by unliganded steroid nuclear receptors may involve a variety of co-activators and coreceptors. We next examined the co-expression of TR and $\beta 1 \mathrm{AR}$ in $\mathrm{CV}-1$ cells that lack endogenous steroid nuclear receptors and have been used extensively for recombination studies of nuclear receptor transactivation. As can be seen in Figure $2 A$, co-transfection of TR $\beta$ alone was associated with a 5 -fold increase in $\beta 1 \mathrm{AR}$ transcription activity in CV-1 cells. The addition of T3 had no further effect on activity. Recent studies have suggested unliganded transcriptional activation may involve other steroid nuclear receptors (10). To examine this question, we co-transfected RAR with the $\beta 1 \mathrm{AR}$ construct alone and with concomitant treatment with retinoic acid. Similar to transfection with $\mathrm{TR} \beta$, co-transfection of RAR alone increased $\beta 1 \mathrm{AR}$ promoter activity by more than 10 -fold. Treatment with retinoic acid decreased this effect by $>60 \%$ (Fig. $2 A)$. Recent studies also suggest cross-talk among the steroid nuclear receptors (10). In some instances, these interactions are stimulatory and in others result in repression of gene transcription. To examine the effects of other steroid nuclear receptors

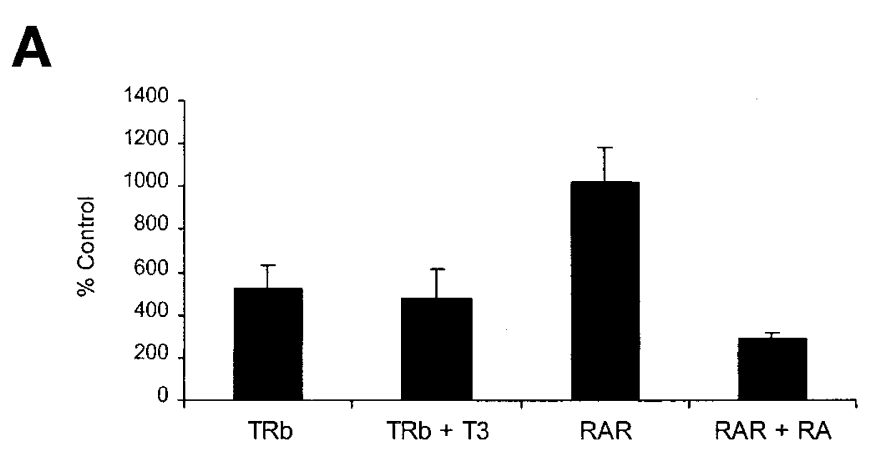

B

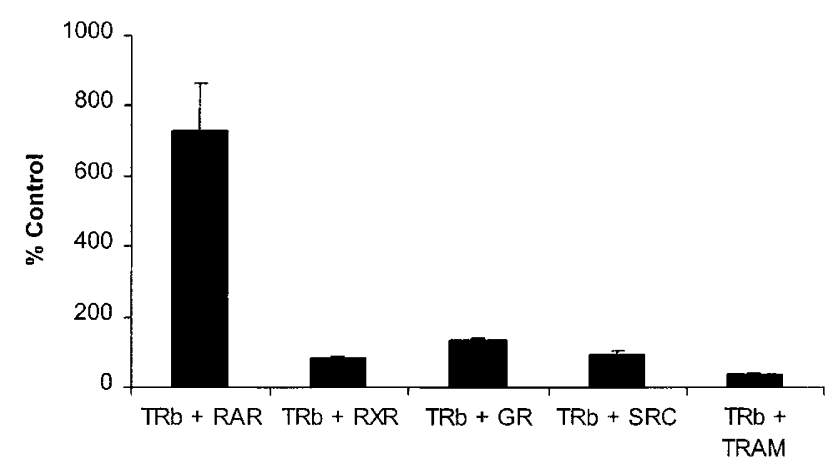

Figure 2. The full-length $\beta 1 \mathrm{AR}$ expression vector was co-transfected with either TR $\beta$ or other expression vectors for steroid nuclear receptors or coactivators as indicated here and described in the text. $\beta 1 \mathrm{AR}$ expression is in $\mathrm{CV}-1$ cells and is expressed as percentage of control/empty plasmid with similar treatment. Mean \pm SEM. 
on the unliganded actions of TR $\beta$, we transfected the $\beta 1 \mathrm{AR}$ promoter alone and in combination with $\mathrm{TR} \beta, \mathrm{RAR}, \mathrm{RXR}$, and glucocorticoid receptor. We also examined the effects of coexpression of TR $\beta$ with TRAM or SRC, two important coactivators for TR-dependent regulation in some systems (43). The results are shown in Figure $2 B$. Co-expression of TR $\beta$ with RAR attenuated the effects of RAR alone (7-fold versus 10 -fold) on $\beta 1 \mathrm{AR}$ promoter activity. Co-expression of RXR, glucocorticoid receptor (GR), SRC, or TRAM significantly attenuated the unliganded effects of TR $\beta$ on $\beta 1 \mathrm{AR}$ activity in this expression system.

To examine whether the effects of unliganded thyroid receptor were due to use of transformed cell lines, the effect of TR alone and in combination with thyroid hormone on the $\beta 1 \mathrm{AR}$ promoter was examined in primary neonatal rat cardiomyocytes. Rat primary cardiomyocytes were transfected with $\beta 1 \mathrm{AR}$ in combination with either vehicle, $\operatorname{TR} \beta$ alone or $\operatorname{TR} \beta$ plus T3. As illustrated in Figure 3, there was a significant increase in $\beta 1 \mathrm{AR}$ luciferase activity after transfection with TR $\beta$ alone, consistent with unliganded hormone receptor transactivation. This activity was returned to nearly control levels when thyroid hormone was added.

The effects of unliganded nuclear receptors on gene regulation may be localized to discrete DNA elements or may be indirect via interaction with other transcription factors operating on other DNA elements (5-9). The precise cis-elements mediating negative regulation by thyroid hormones have not been well characterized in any genes. Therefore, to identify potential elements mediating the effect of unliganded receptor and to examine if the negative regulation mapped to a discrete area, neonatal rat cardiomyocytes were transfected with deletion constructs of the $\beta 1 \mathrm{AR}$ promoter and treated with either T3 alone, TR $\beta$ alone, or TR $\beta$ plus T3. Data for luciferase activity are expressed as the percentage of the vehicle control. The constructs are depicted in the legend of Figure 4. As was seen earlier with the full-length, 2333-bp construct, co-transfection of TR $\beta$ resulted in a significant increase in transcription activity. Treatment with $\mathrm{T} 3$ reduced this effect by $>50 \%$. As shown in the figure, deletion of sequences between -2333 and -2030 resulted in a reduction in the magnitude of the effect of unliganded activation but the increase with TR $\beta$ alone was still nearly 2-fold greater than the control. Addition of T3 still resulted in a 50\% reduction in transcription activity,

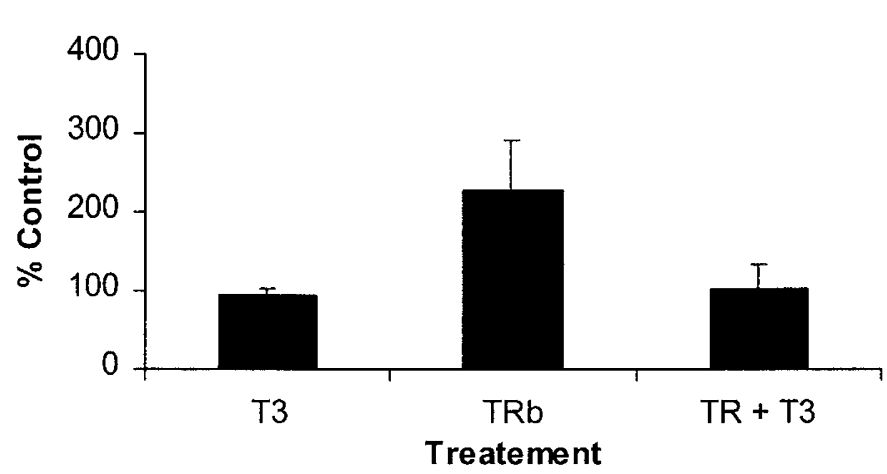

Figure 3. The effects of TR alone or in combination with thyroid hormone. $\beta 1 \mathrm{AR}$ expression is in neonatal rat cardiomyocytes and is expressed as percentage of control/empty plasmid that was treated identically. Mean \pm SEM.

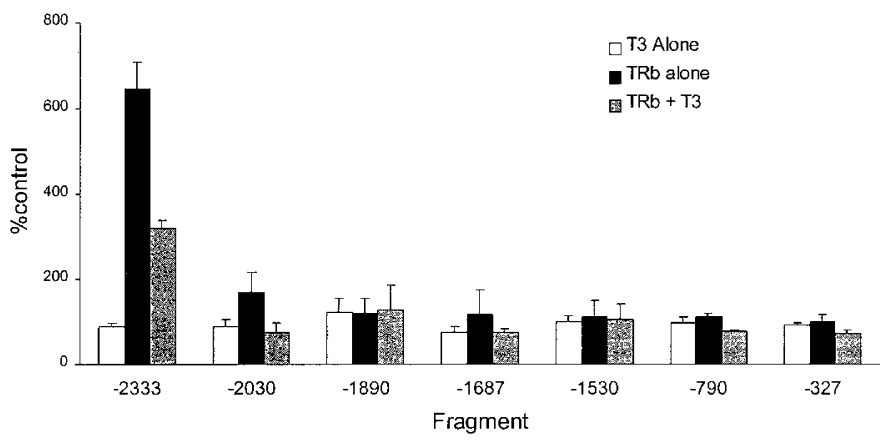

Figure 4. The effects of the TR $\beta$ alone, thyroid hormone alone, or a combination of TR $\beta$ and thyroid hormone on the full-length, 2333-bp promoter and various deletion constructs in neonatal rat cardiomyocytes. $\beta 1 \mathrm{AR}$ promoter activity is expressed as percentage of control/empty plasmid that was treated identically. The horizontal axis shows the size of each deletion mutant relative to the translation start site of the $\beta 1 \mathrm{AR}$. Mean $\pm \mathrm{SEM}$.

suggesting that this fragment retained the suppressive activity associated with addition of thyroid hormone. These effects were not seen in the next deletion mutant or any of the other constructs. We performed a computer search for potential cis-elements on the sequences upstream from -1890 as well as across the full-length promoter using multiple transcription factor databases (44). No canonical TRE or half-sites for TR binding were observed using any of the transcription factor matrices. In addition, we performed DNA footprinting using nuclear protein extracted from isolated cardiomyocytes. We did not see any protected regions across this stretch of sequence (not shown).

Because of their importance in early cardiac embryogenesis and later cardiac growth and development (35-37), and because RAR and RA have been shown to mimic the unliganded effects of TR and T3 on relevant genes like preprothyrotropin releasing hormone (preproTRH) (10), we examined the effects of RAR and RA on $\beta 1 \mathrm{AR}$ expression in primary cardiomyocytes. The $\beta 1 \mathrm{AR}$ was transfected alone or in combination with RAR and treatment with RA. The results are shown in Figure 5. Co-transfection of RAR resulted in a modest increase in

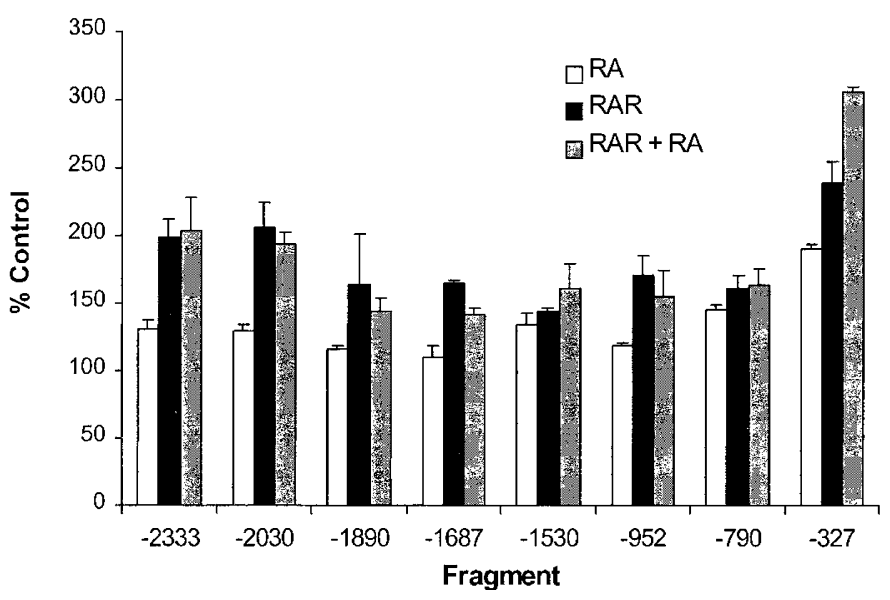

Figure 5. The effects of the RAR alone, RA alone, and a combination of RAR and RA on the full-length, 2333-bp $\beta 1 \mathrm{AR}$ promoter and various deletion constructs in neonatal rat cardiomyocytes. $\beta 1 \mathrm{AR}$ promoter activity is expressed as percentage of control/empty plasmid that was treated identically. The horizontal axis shows the size of each deletion mutant relative to the translation start site of the $\beta 1 \mathrm{AR}$. Mean \pm SEM. 
$\beta 1 \mathrm{AR}$ transcription that was not affected by co-treatment with all trans RA. When similar experiments were carried out with the nested deletions, this effect again mapped to the distal $5^{\prime}$ region of the promoter.

\section{DISCUSSION}

The purpose of these experiments was to identify mechanisms involved in the developmental regulation of $\beta 1 \mathrm{AR}$ gene expression. Our data show that the ovine $\beta 1 \mathrm{AR}$ promoter contains sequences that mediate activation by unliganded TR as well as evidence for suppression of that activity by thyroid hormone. It is not clear if the same sequences are involved in both. The deletion analysis suggests sequences upstream from the proximal promoter are important in the nonligand-dependent activity of the TR. That interaction may involve regulatory sites other than TRE (e.g. AP-1). Unliganded trans-activation of the "full-length" $\beta 1 \mathrm{AR}$ promoter was also seen with the RAR and the addition of RA also decreased the level of transcription.

Over the last several years, a complex picture of the molecular mechanisms involved in thyroid hormone regulation of gene expression has emerged. The mechanisms involved are much more complicated than the classical model whereby thyroid hormone enters the nucleus, binds with its receptor, dimerizes with retinoid $\mathrm{X}$ receptor, and interacts with a canonical TRE in the DNA to affect gene expression (1-4). Of interest in our experiments is the finding that the TR appears to regulate $\beta 1 \mathrm{AR}$ gene expression even in the absence of ligand. Prior investigations have demonstrated similar effects on other genes (5-9). The ability of unliganded TR to both positively and negatively affect gene transcription is indicative of the complex mechanisms of hormonal regulation of gene expression. Fondell et al. (6) showed that unliganded TR can act as an active transcription repressor in HeLa cells. Samuels et al. (8) demonstrated that TR, in the absence of thyroid hormone, increased transactivation via TRE in the rat $\mathrm{GH}$ and prolactin gene promoters but only in specific cell types. Negative regulation of gene expression by steroid receptors is particularly complex. It is dependent on the gene, the cellular context, and the presence or absence of specific co-activators. In the case of the preproTRH gene, TR alone increases expression of reporter constructs that contain the proximal promoter (7). Addition of thyroid hormone results in a marked repression of this transactivation. Further, this effect is augmented by interaction with other nuclear receptors (7).

Adrenergic receptor regulation may be "homologous," as in the case of down-regulation in response to chronic agonist exposure. There is also "heterologous" regulation of adrenergic receptors by nonligand factors such as hormones. Thyroid physiology and receptor occupancy are unique during the perinatal period. The expression of specific thyroid monodeiodinases during intrauterine life converts $\mathrm{T} 4$ to reverse $\mathrm{T} 3$. Reverse $\mathrm{T} 3$ does not bind to nuclear receptors and thus lacks the genomic effects of thyroid hormone. This results in low levels of thyroid hormone in utero in sheep and humans and also in rodents until the postnatal maturation of their thyroid axis (45). The nuclear receptors for thyroid hormones in both rat and sheep are expressed at increasing levels during the latter part of gestation (45-47). Interestingly, there is a low level of TR occupancy in rats until the second postnatal week
(46). Whereas the $\beta 1 \mathrm{AR}$ is expressed and coupled to important physiologic responses, thyroid hormone alone or in combination with corticosteroids does not increase $\beta 1 \mathrm{AR}$ receptor expression or density during fetal or early postnatal development $(17,33,34)$. This is in contrast to studies in older animals and humans where thyroid hormones have clearly been shown to increase $\beta 1 \mathrm{AR}$ expression (28). Our data demonstrating that unliganded TR up-regulates $\beta 1 \mathrm{AR}$ gene expression suggest that unliganded TR stimulation contributes to a constitutively high level of $\beta 1 \mathrm{AR}$ transcription during late fetal and early neonatal life. This in turn contributes to a high level of $\beta 1 \mathrm{AR}$ density at a time when the fetus and newborn are uniquely dependent on sympathetic mechanisms for physiologic adaptation and survival.

Several nuclear receptors other than TR exhibit similar, complex, unliganded effects on transcriptional regulation. Retinoic acid up-regulates the preproTRH gene via an unliganded RAR- RXR mediated mechanism that does not require direct interaction with discrete DNA elements (10). Similarly, transcriptional repression of the $\alpha$ subunit of the pituitary glycoprotein hormones LH and FSH by the AR also occurs independent of direct DNA binding (48). The mechanism of repression requires the DNA binding and ligand binding domains of the receptor, which interact with non-AR elements in the promoter including a cAMP regulatory element. The effects are important for $\alpha$ subunit gene expression in gonadotropes. The orphan receptor CAR- $\beta$ binds to DNA as a heterodimer with RXR and activates gene transcription constitutively in the absence of ligand (49). This transactivation is dependent on the recruitment of transcriptional co-activators. As has been demonstrated for thyroid- and RA-mediated repression of prepro$\mathrm{TRH}$, androstane ligands for CAR- $\beta$ repress transcriptional activation. They do so by promoting release of co-activators from the ligand binding domain (49).

Also important, though not explored as completely as the metabolism of thyroid hormones, is the role of RA in cardiac development in utero. RA, RA binding proteins, and RAR are all important in embryogenesis (35). Because of their importance in cardiac development (36) and because of the significant cross-talk seen with TR and RAR in regulation of other genes $(10,50)$, we examined the effect of RAR on regulation of $\beta 1 \mathrm{AR}$. We demonstrated a significant increase in $\beta 1 \mathrm{AR}$ transcription by unliganded RAR. This is particularly germane to cardiac development where the $\beta 1 \mathrm{AR}$ is most highly expressed. Although the relative level of occupancy of RAR in utero is not known, fetal RA levels are substantially lower than maternal levels at all ranges of concentration (50). Cardiac growth and development are affected importantly by alterations in RA homeostasis (51). Thus, it is likely that RAR-dependent mechanisms, even in the face of reduced fetal RA levels and reduced receptor occupancy, contribute to constitutive expression of $\beta 1 \mathrm{AR}$ during development. The $\beta 1 \mathrm{AR}$, in turn, is critically involved in cardiomyocyte proliferation during the fetal and early postnatal period and cardiac growth in later developmental periods $(19,52,53)$.

Steroid receptor-mediated regulation of gene expression is complex. The levels of complexity contribute to diversity in modes of regulation and allow for potential explanations for the tissue-specific, cell-specific, developmental stage-specific, 
and ligand-dependent and -independent modes of gene expression. In these studies, we showed that unliganded TR and RAR exert important positive transcriptional effects on expression of the $\beta 1 \mathrm{AR}$ promoter. These effects may be particularly important in the context of a developmental period when occupancy of the thyroid nuclear receptor is low and dependence on $\beta 1 \mathrm{AR}-\mathrm{mediated}$ mechanisms are critical for survival.

Acknowledgments. The authors thank Dr. William Chin, Harvard University, for the generous gift of expression vectors.

\section{REFERENCES}

1. Whitfield GK, Jurutka PW, Haussler CA, Haussler MR 1999 Steroid hormone receptors: evolution, ligands, and molecular basis of biologic function. J Cell Biochem 32/33:110-122

2. Beato M, Herrlich P, Schutz G 1995 Steroid hormone receptors: many actors in search of a plot. Cell 83:851-857

3. Katzenellenbogen JA, O'Malley BW, Katzenellenbogen BS 1996 Tripartite steroid hormone receptor pharmacology: interaction with multiple effector sites as a basis for the cell- and promoter-specific action of these hormones. Mol Endocrinol 10:119-131

4. Mangelsdorf DJ, Evans RM 1995 The RXR heterodimers and orphan receptors. Cell $83: 841-850$

5. Sjoberg M, Vennstrom B 1995 Ligand-dependent and -independent transactivation by thyroid hormone receptor beta 2 is determined by the structure of the hormone response element. Mol Cell Biol 15:4718-4726

6. Fondell JD, Roy AL, Roeder RG 1993 Unliganded thyroid hormone receptor inhibits formation of a functional preinitiation complex: implications for active repression. Genes Dev 7:1400-1410

7. Satoh T, Monden T, Ishizuka T, Mitsuhashi T, Yamada M, Mori M 1999 DNA binding and interaction with the nuclear receptor corepressor of thyroid hormone receptor are required for ligand-independent stimulation of the mouse preprothyrotropin-releasing hormone gene. Mol Cell Endocrinol 154:137-149

8. Helmer EB, Raaka BM, Samuels HH 1996 Hormone-dependent and -independent transcriptional activation by thyroid hormone receptors are mediated by different mechanisms. Comp Biochem Physiol C Pharmacol Toxicol 137:390-399

9. Chin WW, Yen PM 1996 T3 or not T3 - the slings and arrows of outrageous TR function. Comp Biochem Physiol C Pharmacol Toxicol 137:387-388

10. Satoh T, Ishizuka T, Monden T, Shibusawa N, Hashida T, Kishi M, Yamada M, Mori M 1999 Regulation of the mouse preprothyrotropin-releasing hormone gene by retinoic acid receptor. Comp Biochem Physiol C Pharmacol Toxicol 140:5004-5013

11. Padbury JF, Hobel CJ, Diakomanolis ES, Lam RW, Fisher DA 1981 Ontogenesis of beta-adrenergic receptors in the ovine placenta. Am J Obstet Gynecol 139: 459-464

12. Habib DM, Padbury JF, Martinez AM, Chappell B, Thio SL, Burnell E 1991 Neonatal adaptation: cardiac adrenergic effector mechanisms after birth in newborn sheep. Pediatr Res 29:98-103

13. Stein HM, Oyama K, Sapien R, Chappell B, Padbury JF 1992 Prolonged beta agonist infusion does not induce desensitization or down-regulation of beta adrenergic receptors in newborn sheep. Pediatr Res 31:462-467

14. Stein HM, Oyama K, Martinez A, Chappell BA, Buhl L, Blount L, Padbury JF 1993 Effects of corticosteroids in preterm sheep on adaptation and sympathoadrenal mechanisms at birth. Am J Physiol 264:E763-E769

15. Padbury JF, Tseng YT, Waschek JA 1995 A cloning strategy for G-protein coupled hormone receptors: the ovine $\beta$ 1-adrenergic receptor. Reprod Fertil Dev 7:521-525

16. Padbury JF, Tseng YT, Waschek JA 1995 Transcription initiation is localized to a TATAless region in the ovine $\beta 1$ adrenergic receptor gene. Biochem Biophys Res Comm 211:254-261

17. Tseng YT, Tucker MA, Kashiwai KT, Waschek JA, Padbury JF 1995 Transcriptional regulation of $\beta 1$-adrenergic receptors by corticosteroids and thyroid hormone in fetal sheep. Eur J Pharmacol (Mol Pharmacol Sect) 289:353-359

18. Tseng YT, Waschek JA, Padbury JF 1995 Functional analysis of the 5' flanking sequence in the ovine $\beta_{1}$-adrenergic receptor gene. Biochem Biophys Res Comm 215:606-612

19. Dzimiri N 1999 Regulation of beta-adrenoreceptor signaling in cardiac function and disease. Pharmacol Rev 51:465-501

20. Hellgren I, Sylven C, Magnusson Y 2000 Study of the betal adrenergic receptor expression in human tissues: immunological approach. Biol Pharm Bull 23:700-703

21. Dixon RA, Kobilka BK, Strader DJ, Benovic JL, Dohlman HG, Frielle T, Bolanowski MA, Bennett CD, Rands E, Diehl RE 1986 Cloning of the gene and cDNA for mammalian beta-adrenergic receptor and homology with rhodopsin. Nature 321:75-79

22. Collins S, Caron MG, Lefkowitz RJ 1991 Regulation of adrenergic receptor responsiveness through modulation of receptor gene expression. Ann Rev Physiol 53:497-508

23. Searles RP, Midson CN, Nipper VJ, Machida CA 1995 Transcription of the rat beta 1 -adrenergic receptor gene. Characterization of the transcript and identification of important sequences. J Biol Chem 270:157-162

24. Collins S, Ostrowski J, and Lefkowitz RJ 1993 Cloning and sequence analysis of the human beta 1-adrenergic receptor 5'-flanking promoter region. Biochim Biophys Acta 1172:171-174
25. Bahouth SW, Cui X, Beauchamp MJ, Park EA 1997 Thyroid hormone induces beta1-adrenergic receptor gene transcription through a direct repeat separated by five nucleotides. J Mol Cell Cardiol 29:3223-3237

26. Tseng YT, Stabila JP, McGonnigal BG, Nguyen TT, Padbury JF 1998 An inverted cAMP response element mediates the cAMP induction of the ovine $\beta_{1}$-adrenergic receptor gene. Biochem Mol Biol Int 46:1127-1134

27. Hadcock CC, Malbion JR 1988 Evidence that glucocorticoid response elements in the 5 -noncoding region of the hamster beta 2 -adrenergic receptor gene are obligate for glucocorticoid regulation of receptor mRNA levels. Proc Natl Acad Sci U S A 85:8415-8519

28. Lazar-Wesley E, Hadcock JR, Malbon CC, Kunos G, Ishac EJ 1991 Tissue-specific regulation of alpha $1 \mathrm{~B}$, beta 1 , and beta 2 -adrenergic receptor mRNAs by thyroid state in the rat. Comp Biochem Physiol C Pharmacol Toxicol 129:1116-1118

29. Lai E, Rosen OM, Rubin CS 1982 Dexamethasone regulates the beta-adrenergic receptor subtype expressed by $3 \mathrm{~T} 3 \mathrm{~L} 1$ preadipocytes and adipocytes. J Biol Chem 257:6691-6696

30. Davies AO, Lefkowitz RJ 1980 Corticosteroid-induced differential regulation of beta-adrenergic receptors in circulating human polymorphonuclear leukocytes and mononuclear leukocytes. J Clin Endocrinol Metab 51:599-605

31. Williams LT, Lefkowitz RJ, Watanabe AM, Hathaway DR, Besch HR Jr 1977 Thyroid hormone regulation of beta-adrenergic receptor number. J Biol Chem 252:2787-2789

32. Lazar-Wesley E, Hadcock JR, Malbon CC, Kunos G, Ishac EJ 1991 Tissue-specific regulation of alpha $1 \mathrm{~B}$, beta 1 , and beta 2 -adrenergic receptor mRNAs by thyroid state in the rat. Comp Biochem Physiol C Pharmacol Toxicol 129:1116-1118

33. Whitsett JA, Pollinger J, Matz S 1982 Beta-adrenergic receptors and catecholamine sensitive adenylate cyclase in developing rat ventricular myocardium: effect of thyroid status. Pediatr Res 16:463-469

34. Padbury JF, Klein AH, Polk DH, Lam RW, Hobel CJ, Fisher DA 1986 The effect of thyroid status on lung and heart beta adrenergic receptors in fetal and newborn sheep. Dev Pharmacol Therapeut 9:44-53

35. De Luca LM 1991 Retinoids and their receptors in differentiation, embryogenesis, and neoplasia. FASEB J 5:2924-2933

36. Means AL, Gudas LJ 1995 The roles of retinoids in vertebrate development. Annu Rev Biochem 64:201-33

37. Colbert MC, Hall DG, Kimball TR, Witt SA, Lorenz JN, Kirby ML, Hewett TE, Klevitsky R, Robbins J 1997 Cardiac compartment-specific overexpression of a modified retinoic acid receptor produces dilated cardiomyopathy and congestive heart failure in transgenic mice. J Clin Invest 100:1958-1968

38. Kiely J, Hadcock JR, Bahouth SW, Malbon CC 1994 Glucocorticoids down-regulate beta 1 -adrenergic-receptor expression by suppressing transcription of the receptor gene. Biochem J 302:397-403

39. Zhong H, Minneman KP 1993 Close reciprocal regulation of beta 1- and beta 2-adrenergic receptors by dexamethasone in C6 glioma cells: effects on catecholamine responsiveness. Mol Pharmacol 44:1085-1093

40. Hajjar RJ, Muller FU, Schmitz W, Schnabel P, Bohm M 1998 Molecular aspects of adrenergic signal transduction in cardiac failure. J Mol Med 76:747-755

41. Miyamoto MI, del Monte F, Schmidt U, DiSalvo TS, Kang ZB, Matsui T, Guerrero JL, Gwathmey JK, Rosenzweig A, Hajjar RJ 2000 Adenoviral gene transfer of SERCA2a improves left-ventricular function in aortic-banded rats in transition to heart failure. Proc Natl Acad Sci U S A 97:793-798

42. Noah DL, Blum MA, Sherry B 1999 Interferon regulatory factor 3 is required for viral induction of beta interferon in primary cardiac myocyte cultures. J Virol 73:10208-10213

43. Martinez de Arrieta C, Koibuchi N, Chin WW 2000 Coactivator and corepressor gene expression in rat cerebellum during postnatal development and the effect of altered thyroid status. Comp Biochem Physiol C Pharmacol Toxicol 141:1693-1698

44. Ghosh D 2000 Object-oriented transcription factors database (ooTFD). Nucleic Acids Res 28:308-310

45. Fisher DA, Polk DH 1989 Development of the thyroid. Clin Endocrinol Metab 3:627-657

46. Rodriguez M, Jolin T 1993 Triiodothyronine receptor complex in developing rat brain and pituitary. Am J Physiol 264:E804-E809

47. Polk D, Cheromcha D, Reviczky A, Fisher DA 1989 Nuclear thyroid hormone receptors: ontogeny and thyroid hormone effects in sheep. Am J Physiol 256:E543-E549

48. Heckert LL, Wilson EM, Nilson JH 1997 Transcriptional repression of the alphasubunit gene by androgen receptor occurs independently of DNA binding but requires the DNA-binding and ligand-binding domains of the receptor. Mol Endocrinol $11: 1497-1506$

49. Forman BM, Tzameli I, Choi HS, Chen J, Simha D, Seol W, Evans RM, Moore DD 1998 Androstane metabolites bind to and deactivate the nuclear receptor CAR-beta. Nature 395:612-615

50. Umesono K, Giguere V, Glass CK, Rosenfeld MG, Evans RM 1988 Retinoic acid and thyroid hormone induce gene expression through a common responsive element. Nature 336:262-265

51. Lelievre-Pegorier M, Vilar J, Ferrier ML, Moreau E, Freund N, Gilbert T, MerletBenichou C 1998 Mild vitamin A deficiency leads to inborn nephron deficit in the rat. Kidney Int 54:1455-1462

52. Schluter KD, Piper HM 1999 Regulation of growth in the adult cardiomyocytes. FASEB J 13:S17-S22

53. Tseng YT, Kopel R, Stabila JP, McGonnigal BG, Nguyen TT, Gruppuso PG, Padbury JF 2001 Beta-adrenergic receptors regulate cardiomyocyte proliferation during early postnatal life. FASEB J 15:1921-1926 